\title{
Information Technology Enabled Services in Promoting Services Marketing
}

\section{Archana G*}

Siddhartha Institute of Engineering and Technology, Vinobha Nagar, Ibrahimpatnam, Telangana, India

\author{
Abstract \\ Organization of paper: \\ - Introduction \\ - Theoretical Framework \\ - Summary and Conclusion \\ Introduction: \\ - Scope of usage of Information Technology Enabled Services (I.T.E.S) in promoting Services Marketing \\ - Conceptual framework of Services Marketing \\ - Importance of usage of IT in trading - e-trade, e-commerce, Net Banking \\ Objectives of the paper: \\ - To explore the services of I.T.E.S in Services \\ - To measure the scope for application of I.T.E.S in promoting Services Marketing \\ - To evaluate the Elements of Promotion of Services Marketing \\ Scope of the paper: \\ The scope extends with a possibility to have I.T.E.S as promotional activities in marketing of services to the end users.

\section{Conclusion:} \\ - I.T.E.S will influence the quality of Services Marketing \\ - I.T.E.S is useful as Promotional activity to promote services Marketing \\ - I.T.E.S will enhance the quality of Services Marketing
}

Keywords: Information technology; Services; Marketing; Liberalization

\section{Introduction}

The booming Information Technology Enabled Services Services Marketing (ITES - SM) has become an emblem of success, a liberalization agenda in India and an ongoing process of Globalization. The ITES - SM has contributed substantially to the rapid economic growth and cultural transformations that have taken place. The study has generated a significant data on a wide range of topics, which include work culture and management practices in ITES - SM providing companies [1].

\section{Services marketing}

In $20^{\text {th }}$ Century service industries have developed a lot in most of the Western countries. Service industries represent a very substantial proportion of both domestic and international trade, and are the major employers in the UK, the USA and other countries. There are number of key factors which have contributed to the development of service industries. New technologies and more complex products have led to an increase and demand for after sales service, and long-term maintenance and support services. Consumers enjoy more affluent lifestyles in today's society then they did fifty years ago, and they also have considerably more free time. This factor has led to the growth in the demand for leisure services and luxury services such as holidays [2].
Services have number of economic activities which will not include a product, is generally served at the time of production of the product and it will be in various forms such as (such as convenience, amusement, timeliness comfort or health) which are usually intangible to purchaser.

\section{Usage of I.T.E.S. in promoting services marketing}

Services marketing have been developed due to the establishment and development of services industries in most of the areas of United States and World economies globally.

\section{Benefits of I.T.E.S}

Increases company's flexibility: Through Business Process

*Corresponding author: Guddati Archana, Assoc. Prof, MBA Department Siddhartha Institute of Engineering and Technology, Vinobha Nagar, Ibrahimpatnam, Telangana, India, Tel: +918790600078; E-mail: nemani.archana@gmail.com

Received September 23, 2016; Accepted October 25, 2016; Published November 05, 2016

Citation: Archana G (2016) Information Technology Enabled Services in Promoting Services Marketing. J Bus Fin Aff 5: 219. doi: 10.4172/2167-0234.1000219

Copyright: @ 2016 Archana G. This is an open-access article distributed under the terms of the Creative Commons Attribution License, which permits unrestricted use, distribution, and reproduction in any medium, provided the original author and source are credited. 
Outsourcing (BPO) which is a part of ITES the companies will increase their flexibility.

Most services provided by I.T.E.S vendors are offered on a feefor-service basis. This helps the company to change their structure of cost from Fixed to Variable cost. A variable cost helps a company to respond to changes very quickly and make the firm more flexible through outsourcing.

One more way in which I.T.E.S contributes to a company's flexibility is that a company focuses on its core competencies, without any burdens from bureaucratic restraints. With this main employees are released from performing non-core operations or administrative processes and can spend more time and energy in building the firm's main businesses.

Another way in which I.T.E.S increases organizational flexibility is by increasing the speed of business processes. Using techniques such as linear programming we can decrease the production time and inventory levels, which can increase effectiveness and controls or decreases cost. Supply chain management (SCM) with the effective use of chain partners and business process outsourcing increases the speed of several business processes.

Lastly, flexibility is one of the stages of organizational life cycle. I.T.E.S helped to convert Nortel from a bureaucratic organization to a very reliable competitor. I.T.E.S therefore helps the firms to retain their speed and ability, which they have to otherwise sacrifice in order to become efficient [3].

A company grows at a faster rate as it will be less constrained by large capital expenditures for people or equipment which may take years together to gradually write-off the cost.

Though the above-mentioned arguments are in favor of I.T.E.S and increases the flexibility of organizations, management needs to be very careful with the implementation of it. The company has to look into the challenges before it decides to engage in business process outsourcing [4].

Another issue is that in many cases there is less scope to differentiate BPO from other with size. They provide same services, have same geographic footprints, same technology stacks, and have same Quality Improvement approaches.

\section{Threats of I.T.E.S}

Risk is the major threat with I.T.E.S. Outsourcing an Information system, can cause security risks both from part of communication and from privacy. The Security of North American or European company data is very difficult when accessed or controlled in the SubContinent. From the perspective of knowledge, a change in attitude in employees, underestimation of present costs and the major risk of losing independence, outsourcing leads to a different relationship between organizations [5].

Risks and threats of outsourcing can be managed, to achieve any benefits. If we are able to manage outsourcing in a structured way, maximizing positive outcome, minimizing risks and avoiding any threats, a Business Continuity Management (BCM) model arises.

\section{Summary and Conclusion}

The service sector has emerged as the fastest sector of the economy throughout the developed world. His growth has been accompanied by a corresponding decrease in the importance within the balance of trade of primary industries such as agriculture and fishing and secondary industries such as manufacturing. The growth of service Industries and the service economy has stimulated interest in services marketing theory and practice. A further development is the internationalization of services.

Changes in lifestyle has led to increased demand for leisure services and foreign travel, for example, while developments in technology have led to increased demand for hi-tech services such as computing. New Technologies have also revolutionized service provision processes through the use of automation and computerized systems. There is every sign that service economy will continue to grow in size and the importance and this will be reflected in future developments in services marketing.

In striving to gain and maintain competitive advantage, both productivity and quality are the key importance. However, the nature of services implies that it is difficult to avoid a trade-off situation, when improvements in service productivity can lead to sacrifices in the level of quality. This is the most sensitive in services marketing where people are the service deliverers. If a bank cashier or travel agent needs to process globally, the Indian software services and ITES-SM industries have introduced a novel management system and work culture into the Indian Work place. I.T.E.S. industry should make strategic decisions to proactively fulfill those needs that will become the dominant players in their respective markets.

\section{Technical developments in services marketing}

With the impact of new technology in services marketing there's a move away from traditionally people-based service to higher degree automation. Transactions such as e-commerce, e-banking, e-trade, BPO, Credit Cards, Paper Currency, e-transfer, FOREX, Information Technology, Electronic Funds transfer and the use of databases have metamorphosed Services Marketing Management. This creates vast opportunities for marketers in service organizations.

Promotion is perhaps the well-developed element of the marketing mix as far as not-for-profit organizations are concerned. Advertising, Sales Promotion, Publicity and Personal selling - are the elements of Promotional mix - have been used regularly. However, promotion has frequently not been designed as a part of an integrated marketing programme, with the result that it has been less effective than it could be.

Advertising and promotion is not-for-profit organizations are generally aimed at the sponsor or contributor market more than the client/recipient market. Campaigns to raise funds utilize mass and specialist media advertising, as well as direct mail and other methods to attract interest.

An important component of the Promotion mix, telemarketing has gained popularly particularly in the developed countries. In the Indian perspective, we find just a beginning and the [3] process has, of course, been initiated by foreign banks. The telemarketing is a process of promoting the business customers more quickly to improve productivity; we can ensure that there is resulting raise in quality.

Generally it is seen that new technology increases the demand for services. It creates opportunities for marketers in service organizations and hence there is influence of quality on services marketing and I.T.E.S. is useful as a promotional activity for services marketing.

\section{References}

1. NASSCOM (2012) Indian IT-BPO Industry. 
Citation: Archana G (2016) Information Technology Enabled Services in Promoting Services Marketing. J Bus Fin Aff 5: 219. doi: 10.4172/21670234.1000219

Page 3 of 3

2. TCS to build a 10,000 seat learning campus in Kerala (Press release). TATA Consultancy Services.

3. Capgemini to set up centre in Kerala (press release).

4. Taranjit SV, Batra GS (2014) Information technology and it enabled services industry in India. International Journal of Computing and Corporate Research 4: $1-18$.

5. Parasuram A (2000) Technology Readiness Index (TRI): A multiple item scale to measure readiness to embrace new technologies. Journal of Service Research 2: 307-320. 